\title{
The contribution of historical aerial and satellite photos to archaeological and geo-archaeological research: case studies in Italy and Turkey
}

\section{G. Scardozzi}

CNR-IBAM, Italian National Research Council, Institute for Archaeological and Monumental Heritage, strada per Monteroni, c/o Campus Universitario, 73100 Lecce, Italy

Received: 25 January 2010 - Revised: 18 April 2010 - Accepted: 20 April 2010 - Published: 17 May 2010

\begin{abstract}
The paper evidences the importance of old aerial and satellite photos of ancient topography studies, with examples concerning archaeological and geo-archaeological research conducted in Italy and Turkey, during a cooperation between the Ancient Topography, Archaeology and Remote Sensing Laboratory (AnTAReS Lab) of the Institute for Archaeological and Monumental Heritage of the Italian National Research Council (IBAM-CNR) and the Ancient Topography and Photogrammetry Laboratory (LabTAF) of Salento University.

The historical aerial photos, i.e. those before the big transformations of the 1950's and 1960's, and the space photos taken in the 1960's and 1970's, particularly useful for the Near East, represent a fundamental tool for the study of the territory. In many cases, in fact, they document landscapes that have been modified by urbanization, building of large infrastructures, transformations in the land use and diffusion of mechanized agricultural methods. Only through the detailed analysis of these aerial and space photos it is possible to recover a fundamental documentation concerning the existence, the location and the layout of archaeological evidence and paleo-environmental elements otherwise lost; so, their use during research is very important for the reconstruction of the ancient topography of urban and territorial contexts.
\end{abstract}

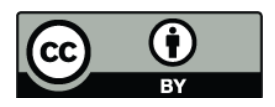

Correspondence to: G. Scardozzi (g.scardozzi@ibam.cnr.it)

\section{Introduction}

The historical aerial photos, i.e. those before the big transformations concerning Italy during 1950's and 1960's (for Italy see Piccarreta and Ceraudo, 2000; Guaitoli, 2003; Scardozzi 2008a), and the space photos taken in the 1960's and 1970's, particularly useful for the Near East (for examples see Galiatsatos, 2004; Beck et al., 2005, 2006, 2007; Ur, 2005 and 2007; Wilkinson et al., 2005; Goossens et al., 2006; Scardozzi, 2008b), represent a fundamental tool for the study of the territory during ancient topography research. In many cases, in fact, they document landscapes which have been greatly modified by urbanization, building of large infrastructures, transformations in the land use and diffusion of agricultural mechanization; these transformations have often radically changed historical landscapes, modifying the morphology of territories or destroying and covering up a lot of ancient evidence. Only through the detailed analysis of old aerial and satellite photos, possibly in integration with ancient cartography, it is often possible to recover, at least partially, a fundamental documentation concerning the existence, the location and the layout of archaeological evidence and paleo-environmental elements otherwise lost.

Some archaeological and geo-archaeological research conducted in Italy and Turkey during a collaboration between the Ancient Topography, Archaeology and Remote Sensing Laboratory (AnTAReS Lab) of the Institute for Archaeological and Monumental Heritage of the Italian National Research Council (IBAM-CNR) and the Ancient Topography and Photogrammetry Laboratory of the Salento University (LabTAF), can evidence the importance of old aerial and

Published by Copernicus Publications on behalf of the European Geosciences Union. 
satellite photos for the ancient topography studies. The examples that I will give in this paper are to show in more detail the importance of the aerial photos acquired before and during the Second World War for research on some ancient sites of Southern and Central Italy. These photos come from the "Fondo S.A.R.A. - Ala Littoria S.A.", which is a collection of numerous aerophotogrammetric flights realized in the 1930's by S.A.R.A. (Società Autonoma Rilevamenti Aerofotogrammetrici) in order to update the cadastral maps of Viterbo Province; also, there are aerial photos realized by the Istituto Geografico Militare (I.G.M.) and the Royal Air Force (R.A.F.) in 1943-1945.

These images, sometimes scarcely used in archaeological research, constitute a very important documentation about urban contexts and territories that later have been changed or partially destroyed; in them it is therefore possible to detect and examine ancient structures and archaeological traces of buried features now no longer visible.

Sometimes paleo-environmental elements that allow the reconstruction of ancient landscapes are also visible in these photos. In these cases the ground check of traces and anomalies visible in the images are very important. Two case studies regard the area of the archaic and Roman harbor of Torre S. Giovanni (south-western Salento, Apulia) and the area of the Yumuktepe, a prehistoric settlement in Mersin (southeastern Turkey). In the first case a very rich multitemporal documentation (between 1943 and 2006) allows us to reconstruct an ancient lagoon (now reclaimed) behind the coastline and the transformation of the last one. In the second case, the analysis and processing of multitemporal space photos taken by reconnaissance United States satellites between 1967 and 1980 allow us to reconstruct the ancient landscape around the Yumuktepe and the valley of the Kizil Dere, that is situated near the settlement; these images also allow the reconstruction of the ancient coastline of the alluvial Adana plain, east of Mersin.

\section{Historical aerial photos for a better understanding of the ancient topography of the Viterbo Province}

In Italy the search of historic aerial photos, often scarcely used in archaeological research, can take place, in the main public archives such as those in the Istituto Geografico Militare (Geographic Military Institute) in Florence and in the Aerofototeca Nazionale of the Istituto Centrale per il Catalogo e la Documentazione (National Aerial Photographic Archive of the Central Institute for Cataloguing and Documentation) in Rome. There is also the possibility of gathering these types of images in minor archives or in those not specialized in the collection of aerial images, such as the State Archive of Viterbo, which conserves a considerable number of aerial photos from the second half of the 1930's, the "Fondo S.A.R.A. - Ala Littoria S.A.", that were recently discovered (Caprasecca, 2006a, b; Scardozzi, 2008a).
The latter are images taken about between 1935 and 1939 by the S.A.R.A. (Sezione Autonoma Rilevamenti Aerofotogrammetrici) of Rome. They were commissioned by the Minister of Finance, General Directorate of Land Register and Technical Services, and used airplanes of the Ala Littoria Società Aerea, in order to upgrade the maps of the Pontifical Land Register of the Viterbo Province and remained in use after the unification of Italy. In the 1930's S.A.R.A., which was part of O.M.I. (Ottica Meccanica Italiana), obtained many commissions both in Italy and abroad, among which was one to carry out the surveys for the creation of the new land register maps of the Province of Viterbo, of Terni as well as for parts of Rome and Sondrio (Piccarreta and Ceraudo, 2000; Boemi, 2003). These areas were surveyed both in plan and in altimetry with the aerophotogrammetric method, here applied for the first time to land register mapping. The commission given to S.A.R.A. was part of the works aimed at the creation of the New Land Register (ordered by the laws 1 March 1886, no. 3682, and 21 January 1897, no. 23). The works started in 1934 after the new unified text of laws on the New Land Register (Testo Unico delle leggi sul Nuovo Catasto) was approved with Royal Decree 8 October 1931, no. 1572.

The "Fondo S.A.R.A. - Ala Littoria S.A." is formed by glass slides $13.18 \mathrm{~cm}$, roughly on a scale of $1: 10000$ 1:11 000, shot with a Nistri photo-camera that created stereoscopic strips from a sequence of inclined pairs of frames that cover entirely the same area. They were taken one frontwards and one backwards with a $6^{\circ}$ inclination; therefore these are stereoscopic images that generally have almost symmetric viewpoint angles. For each Municipality of the Viterbo Province there are printed enlargements on a scale of about $1: 4500$, about $27.8 \cdot 37.8 \mathrm{~cm}$, with further enlargements on a scale with a greater denominator for urban centres. They are often paired with the "Drafts of the limits of private properties" ("Abbozzi di delimitazione delle proprietà private"), which are extracts of the former Pontifical Land Register updated with aerial photos, often containing notes on archaeological remains, taken during a direct survey.

The aerial photos of the "Fondo S.A.R.A.- Ala Littoria S.A." allow us to have a view of large parts of the Viterbo Province before any transformations (natural, but mostly anthropic) of the second post-war period and allow us to gather a considerable amount of extremely important data for the study of ancient topography, town planning and generally of the territory of this area. They offer, in fact, a very wide cover and great detail, while before the I.G.M flight of 1954, the only vertical images previously available were the photos taken by the reconnaissance flights of the Royal Air Force between the years 1943 and 1944, which covered only partially the territory.

In the last year these images were widely used in the course of research aimed at the creation of archaeological maps carried out in cooperation with the Chair of Ancient Topography (Gianfrotta) of the University of Tuscia-Viterbo 


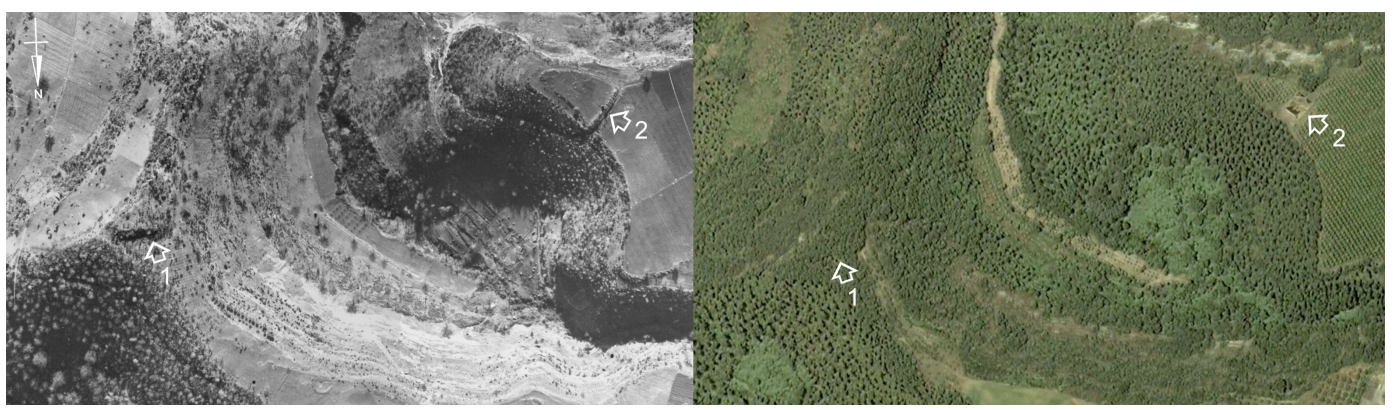

Fig. 1. The remains of two small ancient settlements in the territory between Vitorchiano and Bomarzo (Viterbo Province) in an aerial photo of the "Fondo S.A.R.A. - Ala Littoria S.A." of the second half of 1930's and in a pan-sharpened Ikonos-2 image (colour composite RGB 3-2-1) of 29 May 2005: the old image show clearly the moats and the defensive walls of the settlement of Camorella (1), now covered by vegetation, and of the settlement of Pranzovico (2), now destroyed by modern structures.

(Scardozzi, 2008a; Gasperoni and Scardozzi, 2010). This research included the study of ancient centres and road systems of Etruscan, Roman and Medieval periods located in the municipalities of Viterbo and Fabrica di Roma (for example, the ancient sites of Norchia, Castel d'Asso, Musarna, Ferento and Falerii Novi) and for the study and historical reconstruction of territories such as those of Vitorchiano, Bomarzo, Soriano nel Cimino, Vignanello and Corchiano, in the eastern part of the Viterbo Province. These images allowed us to recover abundant data that would have otherwise been lost, thus forming an exceptional documentation, of low elevation, areas transformed by agricultural activities or by the expansion of modern urban centres. Furthermore, many photos were taken in winter months, so that the extensive forest areas that characterize the investigated territory appear with a less rich vegetation compared to today. This allows for an easier understanding of visible ancient remains, the reading of their planimetric articulation and their spatial characteristics (Fig. 1).

\section{Multitemporal aerial and satellite photos for the study of the Torre San Giovanni coastal territory (Lecce province)}

The historic aerial images not only allow us to recover important data on archaeological evidence and ancient contexts that would otherwise be lost, but often permit us to reconstruct historic landscapes that have been subsequently transformed. In fact, sometimes in these photos paleoenvironmental elements are so visible that we are able to reconstruct ancient landscapes. In these cases the ground check of visible traces and anomalies in the images is very important.

In the study of the area of the Archaic, Roman and Medieval harbor of Torre S. Giovanni (south-western Salento, Lecce Province) a rich multitemporal aerial and space photo documentation (between 1943 and 2006) allows us to reconstruct an ancient lagoon (now reclaimed) behind the coastline and the transformation of the latter. The analysis of this stretch of the Salento coastline was carried out in the scope of a territorial research project is the result of an agreement between the Municipality of Ugento, the Department of Cultural Heritage of the University of Salento and the Superintendence for Archaeological Heritage of Puglia. The research project included the excavation (directed by Bietti Sestieri, Chair of European Protohistory of the Salento University) of the so-called Specchia Artanisi, a funerary complex located about $2.5 \mathrm{~km}$ south-west of Ugento (Lecce) and formed by three large tumuli (diameters between 15 and $25 \mathrm{~m}$ ) consisting of accumulation of arranged rocks, that cover four large crate tombs with lithic slabs dating from the Early and Middle Bronze Age. The stratigraphic excavations, carried out in June-July 2008 and in SeptemberOctober 2009, were integrated with a systematic archaeological survey of the surrounding territory (carried out by LabTAF and IBAM-CNR), between the modern towns of Ugento and Torre San Giovanni. This allowed us to locate at least one of the settlements to which the burials belonged and to reconstruct the condition of the ancient topography (Scardozzi, 2009).

The Specchia is located along the border of the last reliefs overlooking the Ionic coast (about $25 \mathrm{~m}$ a.s.l.), about $2 \mathrm{~km}$ away. A distinct natural step (about 10-15 m high) separates the site from the coastal plain that extends east and southeast from Torre San Giovanni. The current situation of this stretch of coast appears strongly modified compared to ancient times and a contribution to the reconstruction of the paleo-environment is offered both by the historic cartography and by the aerial and space photos taken before the transformations of the last decades. In fact, the areas immediately south of the Specchia Artanisi, between Torre San Giovanni and Pescoluse, were occupied by a coastal lagoon, today interred and by an extensive marsh area (over 400 ha), separated from the coast by a line of dunes and also remembered 


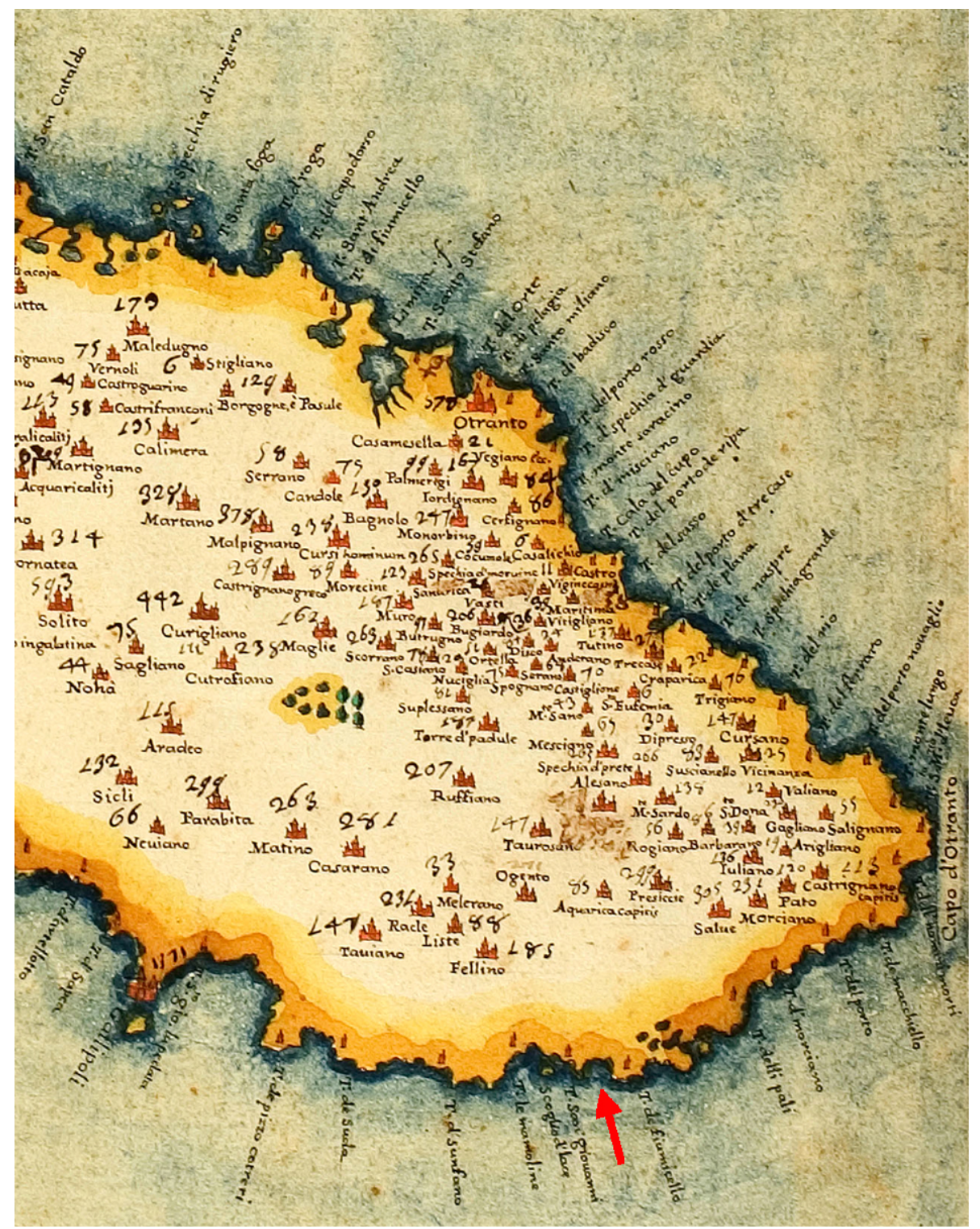

Fig. 2. A detail of the "Provincia di Terra d'Otranto" (1613) drawn by Mario Cartaro (National Library of Naples): the shadow indicate deep bay to the south of the promontory of Torre San Giovanni (Lecce Province), protruding into the sea more than today.

in the toponymy (Padule Bianco, I Paduli, Paduli degli Sponderati - "Padule" in local language is "Palude", "marsh"), reclaimed between 1932 and 1952 (Lezzi, 2000).

This lagoon seems to have been schematically documented before it was completely interred by the cartography of XVI and XVII centuries, which shows that the promontory of Torre San Giovanni was once more isolated and extended in a south-west direction than it is today (Fig. 2).

The aerial images taken by the I.G.M. in 1943 (Fig. 3), 1947 and 1955 allow for the reconstruction of the ancient appearance of this area, of the geomorphology of the coastline and of the overlooking sea-shoals, showing evident traces of residual humidity and ancient dune stretches. They fur- thermore document the progressive reclaim of the brackish coastal area, by means of both the successive construction of two tide canals and several basins, and the filling of many land. The ancient situation included a high coast, lined by a rock stepped bank, that changed to a low sandy shoreline, in front of which a long and narrow lagoon was formed, now reclaimed (Schmiedt, 1975; Pizzurro, 2002). The stretch of beach that defines it is overlooked by a series of sea-shoals (the so-called "Secche di Ugento") that expand offshore for at least 2 miles, signalled in the portolan chairts as dangerous. Along the promontory called "Palmentello", on which in 1565 Torre San Giovanni was built, there is a natural bulwark, formed by a sea cliff that extends for about $1200 \mathrm{~m}$ 


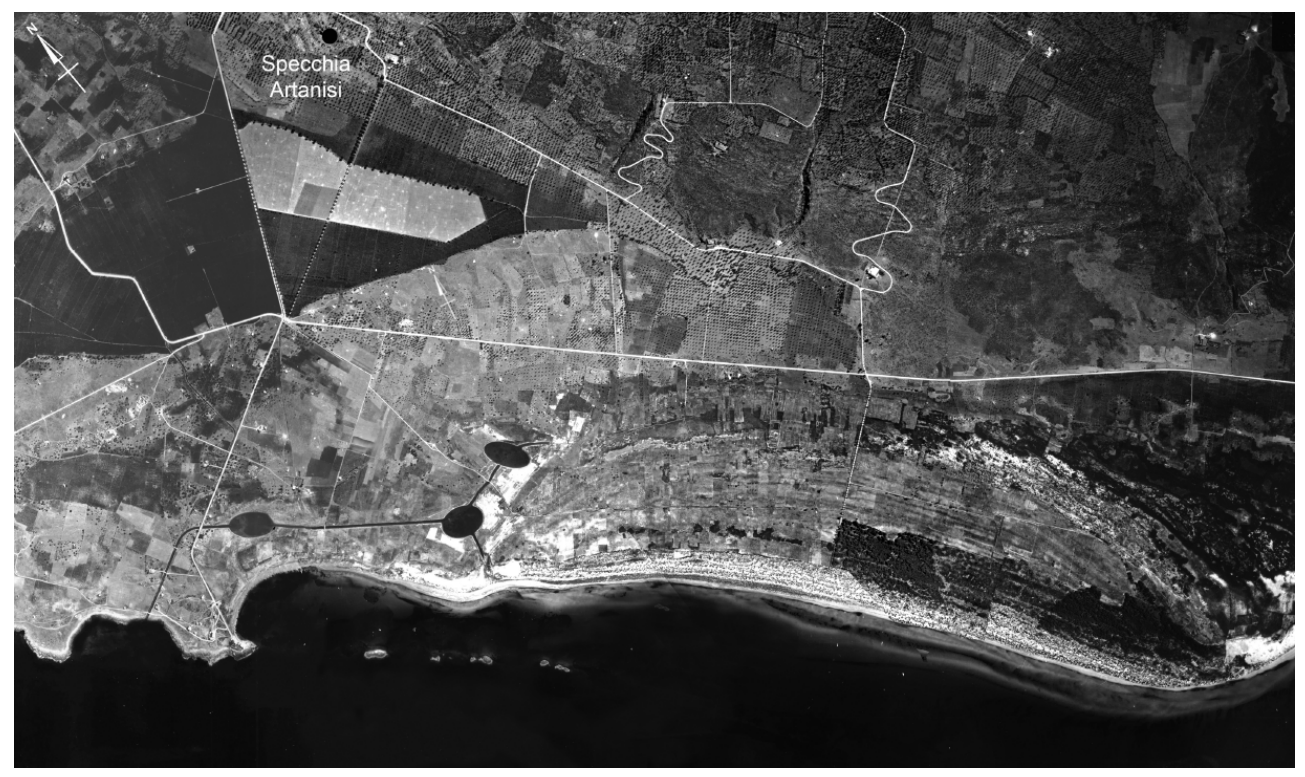

Fig. 3. Mosaic of I.G.M. aerial photos of 1943 (strip 47, photos 210-212) with the area between Torre San Giovanni and Torre Mozza; along the coast have already been made basins Suddenna, Bianca and Ulmo.

parallel to the sandy shoreline, standing about $200 \mathrm{~m}$ from it (D'Alessandro et al., 1998). In historic times this natural canal and the now non-existing lagoon were occupied by the harbour near Torre San Giovanni, that formed the Messapian, Roman and Medieval port of Ugento. The archaeological remains document that there was a presence in the harbour area at least from the Archaic age up to High-Medieval times (Urso, 1941; Zecca, 1963; D’ Andria, 1978; D’Andria, 1979; Zecca, 1980; D’Andria, 1983; Desy, 1983; D’Andria, 1988; D'Andria, 1991; Desy and De Paepe, 1990; Lamboley, 1996; Semeraro, 1997; Pizzurro, 2002; Auriemma, 2004).

The current appearance of this port area is very different from the ancient one, since the original natural pier is now broken in seven parts due to eustatism, while the opposite sandy shore is constantly being modified by the effect of marine currents, that widen the shoreline in some areas, while reducing it in others. In the northern part the shore line is now about $30 \mathrm{~m}$ wider since the recent construction of two piers. Instead, in the southernmost area, in the direction of Lido Marini, an intense phase of overwashing took place resulting in a reduction of the coast of up to about $100 \mathrm{~m}$ (Mastronuzzi et al., 1987). The examination of the photos from the 1940's and 1950's and the comparison with the later aerial images available (A.M. - Aeronautica Militare 1968, Istituto Geografico Militare 1972, Società Rossi 1979, AeroTop 1988, C.G.R. - Compagnia Generale Riprese Aeree 1997 and 2006), highlight the transformations in the area of Torre San Giovanni and Lido Marini. The documentation offered by the aerial images was also integrated by some high resolution satellite images, particularly by space photos that were taken on 12 September 1961, 12 Decem- ber 1968 and 24 July 1970, respectively by United States spy satellites Corona KH-3 (mission 9022; ground resolution about $7.5 \mathrm{~m}$ ), Corona $\mathrm{KH}-4 \mathrm{~A}$ (mission 1049; geometric resolution about $2.75 \mathrm{~m}$ ) and Corona $\mathrm{KH}-4 \mathrm{~B}$ (mission 1111 ; geometric resolution of about $1.80 \mathrm{~m}$ ). Some of the few photos that are available for Italy, belonged to strips that include Greece and the Balkan area, as well as a QuickBird-2 image, with a ground resolution of $0.6 \mathrm{~m}$, acquired on 13 May 2004. The aerial and satellite images document how in the last decades there has been a strong expansions of the urban areas, significant modification in the use of the terrain (with an extension of olive groves to the detriment of the areas previously occupied by arable fields, scrub and garrigue) and a deep alteration of the coastline (Fig. 4): in particular, the construction of the small tourist pier at Torre San Giovanni has modified the currents, thus varying the normal regime of transportation and sedimentation along the sandy coast. Further south, the stretch of coast near the "Rottacapozza Sud" basin was affected by an extremely strong erosion phenomenon, with the disappearance of the original dune line and a strong reduction of the coastline (Dadamo et al., 2008a, b).

The Specchia Artanisi was thus located in a dominant position and was well visible from the sea, along a coast stretch higher and more articulated that it appears today. It offered favourable conditions for docking, thanks to the coastal lagoon (it also constituted a natural environment that favoured fishing and hunting) and to the presence of fresh water springs. The small settlement of huts to which the Specchia belonged was located about $170 \mathrm{~m}$ west of the funerary area, on a small rocky promontory that extended westwards. The 


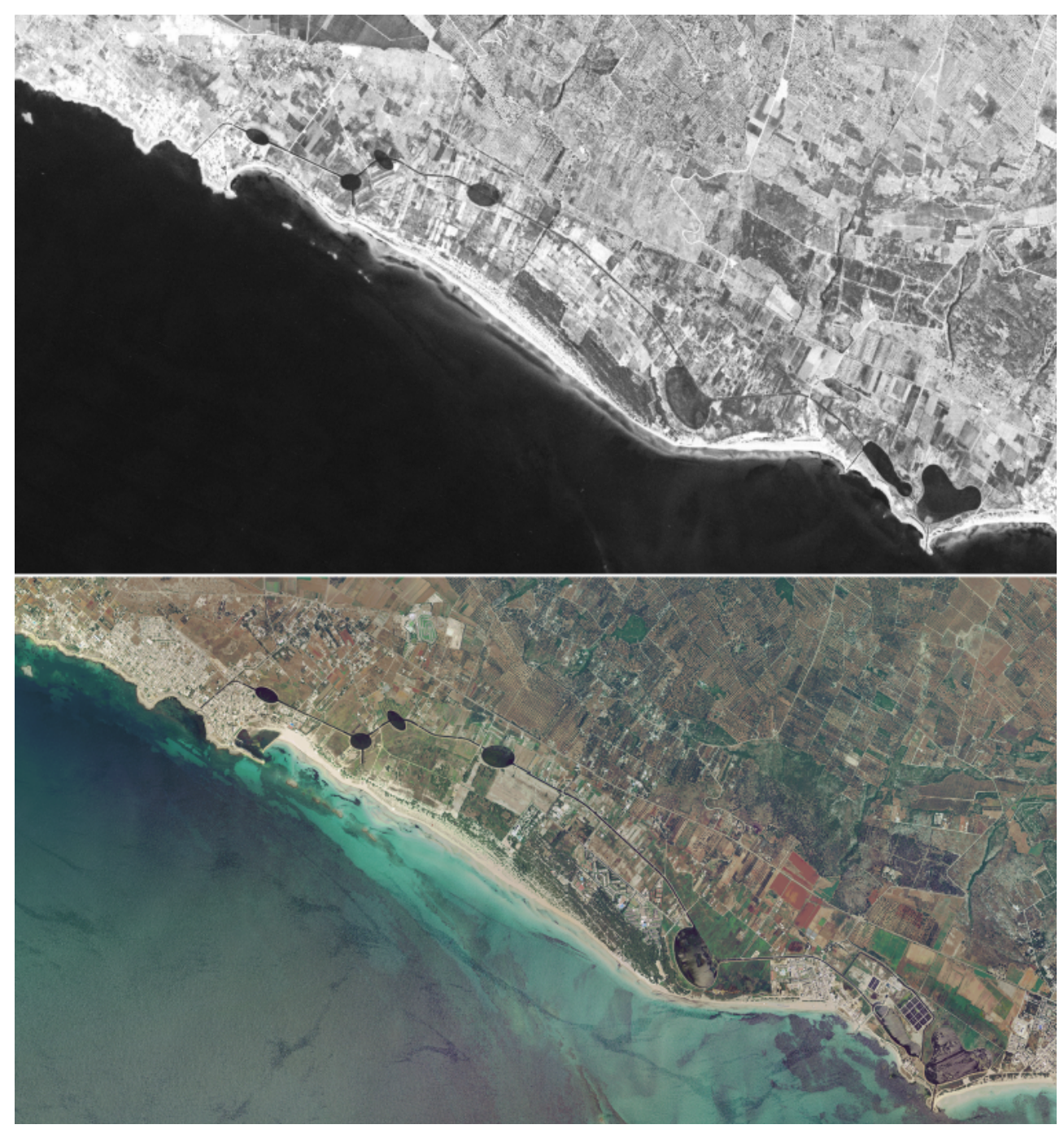

Fig. 4. The coast between Torre San Giovanni and Torre Mozza in a Corona KH-4B space photo of 1970 and in a C.G.R. aerial photos of 2006 (sezione 536100).

presence of this settlement, located in a dominant position for the control of the coast line and of the lagoon sited immediately south, is today documented by potsherds scattered on the surface of fields, as strongly altered and affected by agriculture (planting of olive trees) and obliterated by shifted earth. In any case, it cannot be excluded that in the area east of the Specchia Artanisi other small settlements existed that could have used the same funerary area, but surface research have not shown the presence of other protohistoric sites.

The historic aerial images also document the Specchia before the recent agricultural interventions that have partially altered its borders (mostly the western and eastern ones), and the morphology of the area immediately north of the monument before the transformations of recent years when a natural canal that interrupts the rock step and slopes from northeast to south-west was filled with debris.

\section{Historical space photos for the reconstruction of the ancient topography around the Yumuktepe (Mersin)}

During the course of archaeological and aerial-topographical research carried out in Italy, the historical satellite images are an accessory documentation, that integrate the vast availability of old aerial images. The situation in the Near East is often different and satellite imagery represents a fundamental documentation, if not the only available. Such is the case, for example, in the research aimed at the reconstruction of the ancient topography and the paleo-environment of the area of the Yumuktepe, in the western periphery of Mersin, and of the near (toward the east) coastal plain of Adana (south-eastern Turkey). These geo-archaeological investigations were carried out during the research activities of the Italian Archaeological Mission under the direction of Caneva (Salento University, Chair of Protohistory and Prehistory of 


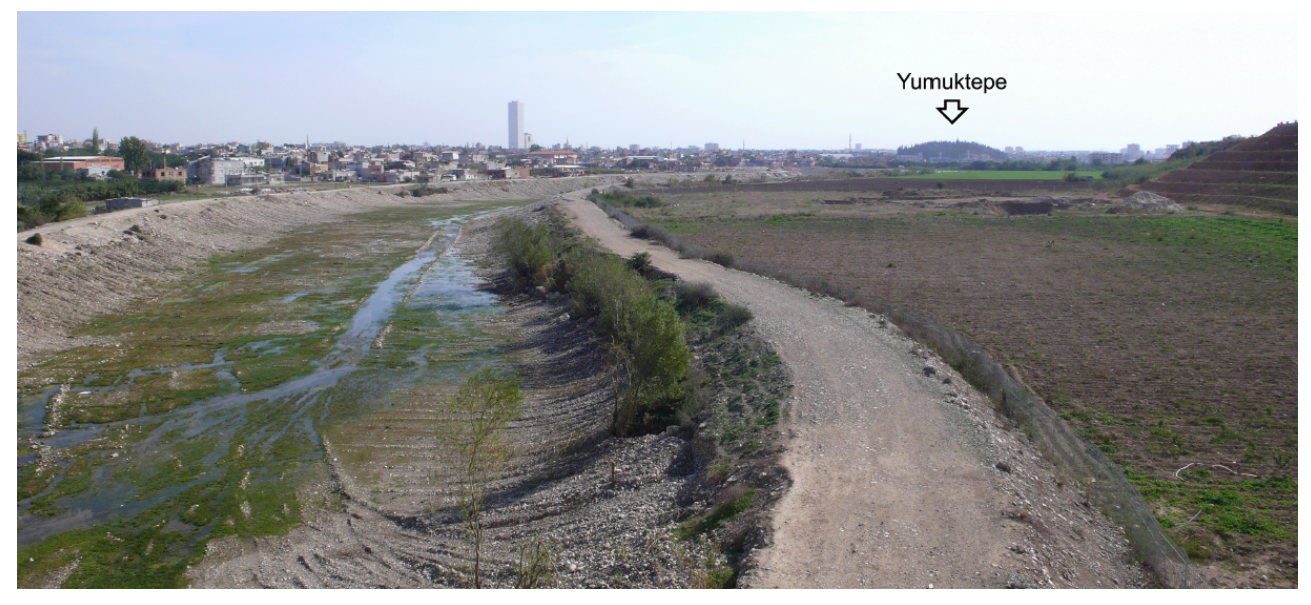

Fig. 5. A view of the Kizil Dere Valley north-west of the Yumuktepe (2008).

the Near East). In this case, the analysis and processing of multitemporal space photos taken by United States reconnaissance satellites between 1967 and 1980 allow us to reconstruct the ancient landscape around the Yumuktepe, a tell sited at the eastern margin of the Adana plain and settled from the Neolithic age (7000 BC) up to the Byzantine period (but with the absence of any Roman or Roman-related settlement), located at the western periphery of Mersin (Caneva and Sevin, 2004), and of the valley of the Kizil Dere River, that flows west of the mound, closely bordering and badly eroding its edge. These images also allow us to understand and document the formation process of the alluvial Adana plain and to reconstruct the ancient coastline.

In the course of the research, lacking an adequate cartographic and aerial-photographic documentation, historic satellite images were thus recovered which would show the investigated territory before the transformations of recent years, that included a considerable expansion of Mersin and of the other urban centres in the Adana plain, and the development of several industrial buildings. The images were recovered in different detail scales, according to the specificity of the research: in particular, one Gambit KH-7 image taken on 8 February 1967 (mission 4036; geometric resolution $0.6 \mathrm{~m}$ ), one image of the Corona KH-4A satellite taken on 8 August 1967 (mission 1043; geometric resolution about $2.75 \mathrm{~m}$ ), three images from the Corona KH-4B satellite taken on 14 May 1968, 31 July 1969 and 10 March 1970 (missions 1103, 1107 and 1109; geometric resolution about $1.80 \mathrm{~m}$ ), and two images of the Hexagon KH-9 satellite taken on 17 June 1975 and 18 July 1980 (missions 1210 and 1216; geometric resolution 6-9 m) were collected. Together with these images that document the evolution of the territory in the 1960's and 1970's, another was recovered from QuickBird2, taken in 29 December 2007, in order to have a comparison with the current situation. Instead, historical aerial photographs prior to 1967 are not available.
Regarding the study aimed at the reconstruction of the ancient morphology of the area in which the Yumuktepe is located and at in the point where the Taurus foothills come closest to the Mediterranean coast (south-eastern Cilicia), the examination of the remote sensing data was accompanied by ground checking of the visible traces and evidence in the images along the course of the Kizil Dere River (Fig. 5), for a stretch of about $3 \mathrm{~km}$ upriver of the tell. The surveys reached the area of Karaisal, where the river sharply turns south-east. The geologic studies showed that it was formed by a rising of the territory immediately east of the water course, which occurred in a quite recent geologic age (Caneva and Marcolongo, 2004).

The main aim of the research was to reconstruct the ancient river course, that today runs west of the Yumuktepe. For this investigation, satellite images from the end of the 1960 's resulted particularly helpful, having provided a very detailed image of the tell surrounding territory before the urban expansion of Mersin reached it (Fig. 6). In fact, today it is almost completely surrounded by urban areas, as is the river course between the hill and the sea (about $2.3 \mathrm{~km}$ ). Furthermore, the Kizil Dere River bed was lined with artificial banks in the 1970's. Consequently the historic images document the situation that preceded these interventions on the river (Fig. 7), showing that when overflowing occurred it had a tendency to move in an east-west direction inside a quite wide alluvial plain, formed by the sediment left behind by the water course and defined by two slopes $2-3 \mathrm{~m}$ high.

The examination of the satellite images, integrated with surveys carried out in the areas not yet urbanized and the study of the available geologic charts (in which the alluvial contribution of the Kizil Dere in the historic period were highlighted), allowed us to reconstruct the alluvial plain through which the river flowed near the tell that was located at the centre of the plain itself, and about $1 \mathrm{~km}$ nearer to the sea as compared to today (Fig. 8). Thus the seashore has advanced less than in the near Adana plain (see above). The 


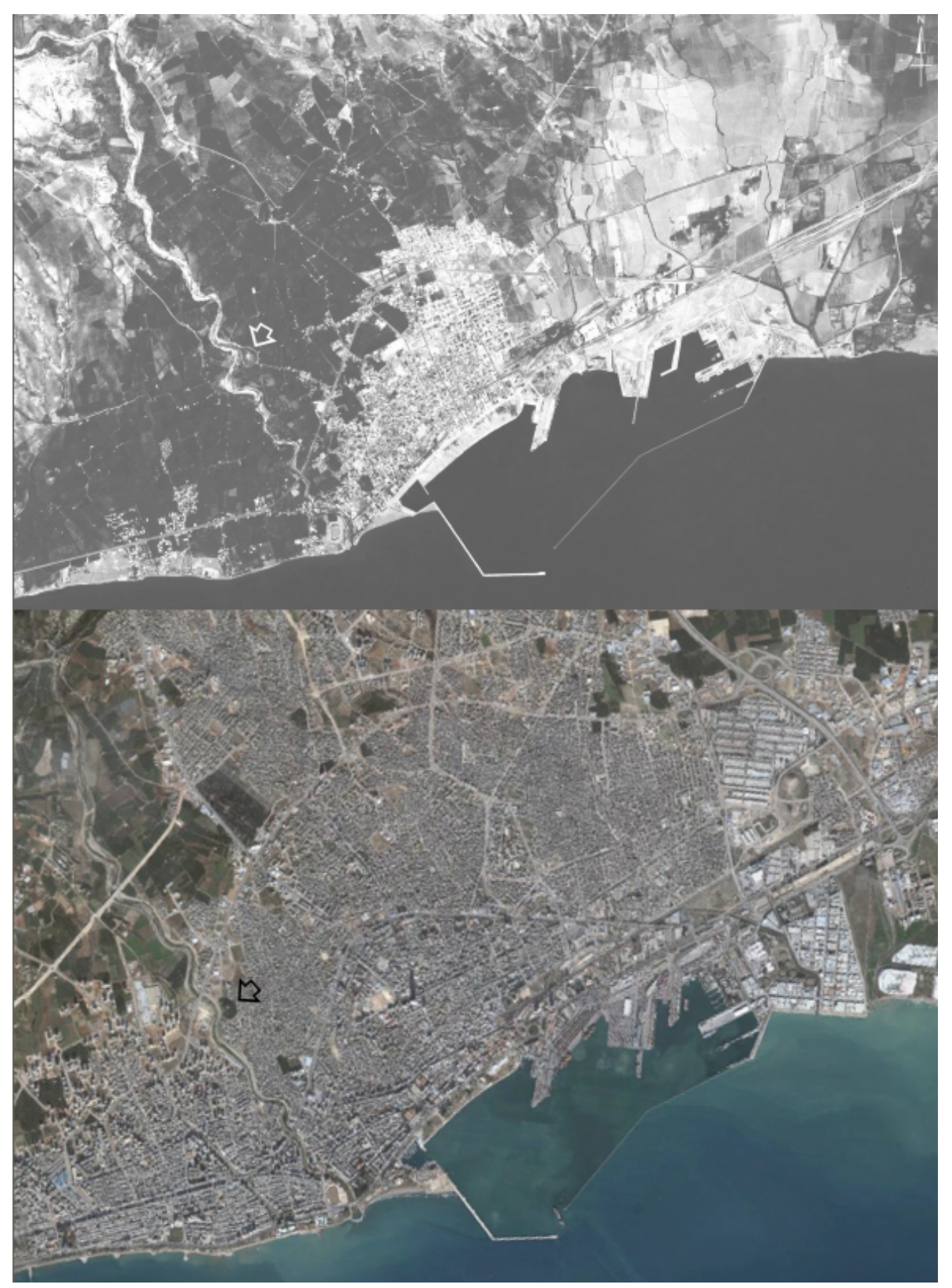

Fig. 6. Mersin in a Corona KH-4B space photo of 1968 and in a QuickBird-2 pan-sharpened image (colour composite RGB 3-2-1) of 2007: the shadows indicate the Yumuktepe.

investigations thus allowed us to reconstruct the morphology of the area in prehistoric and protohistoric times, evidencing several paleo-beds of the Kizil Dere both west of Yumuktepe, where it flows today, and east, where, according to a hypothesis formulated a few years ago on the basis of a geological study (Caneva and Marcolongo, 2004), it is likely that in the past the river flowed. In this area, today urbanized, the ancient alluvial plain was partially filled in. Considering also the data from the archaeological excavations of the Tepe, where, for example, one of the gates of the Chalcolithic Citadel (5000-4200 BC) was uncovered on the north-western slope of the mound near the Kizil Dere, it seems that the present location of the river course is due to a very recent, post-occupational (i.e. after the Byzantine period), phenomenon, perhaps following an important tectonic movement. This change of the hydrographic situation might also have been the cause for the abandonment of the settlement. For the examination of the Adana plain and for the reconstruction of the prehistoric and protohistoric coastline in the area east of the Yumuktepe, the integrated analysis of the 3-D terrain model based on data of the Shuttle Radar Topography Mission, and of the historic satellite 


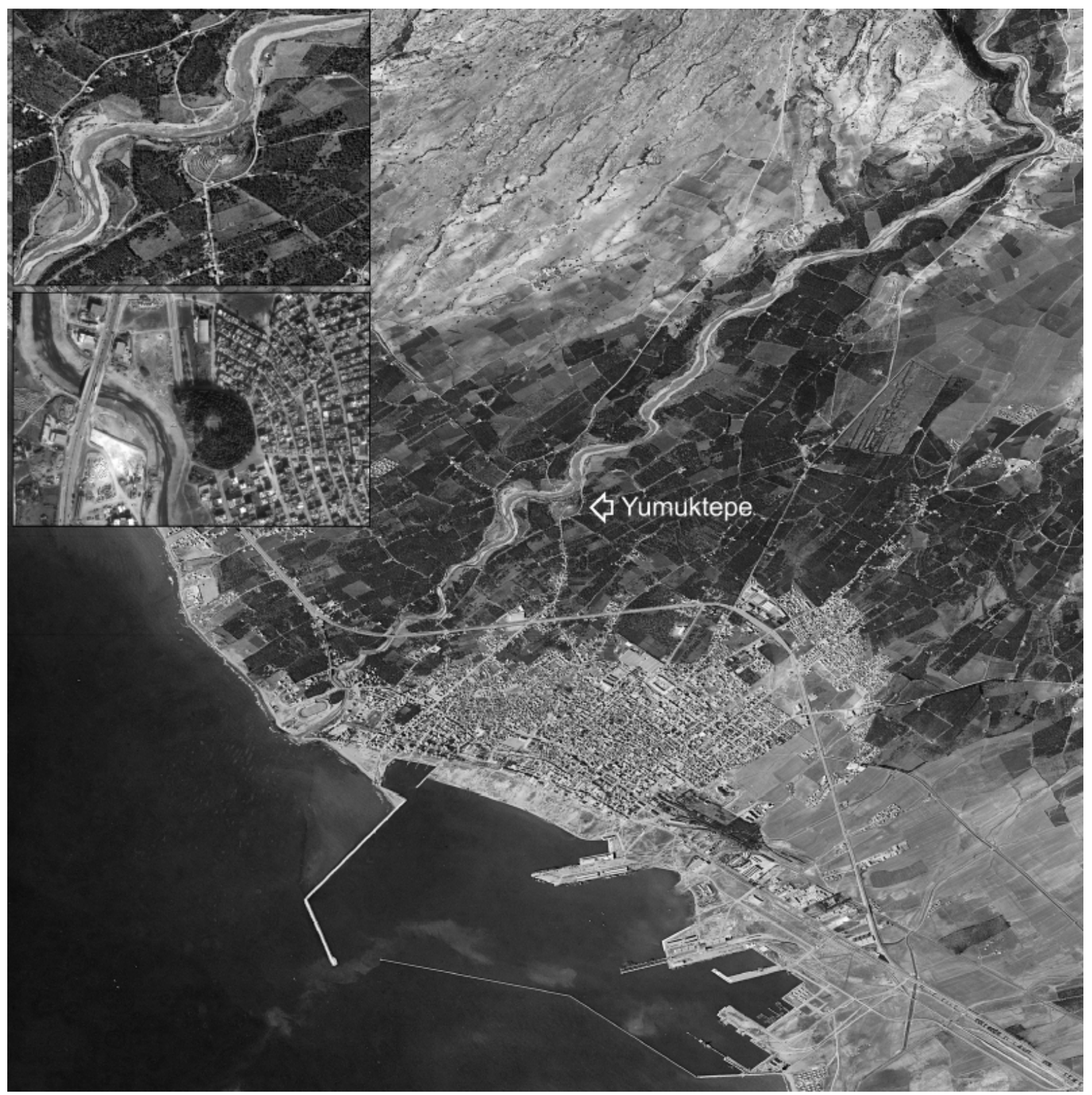

Fig. 7. Mersin in a Gambit KH-7 photo of 1967: in the squares two views of the Yumuktepe in the same image and in a QuickBird-2 panchromatic image of 2007. 


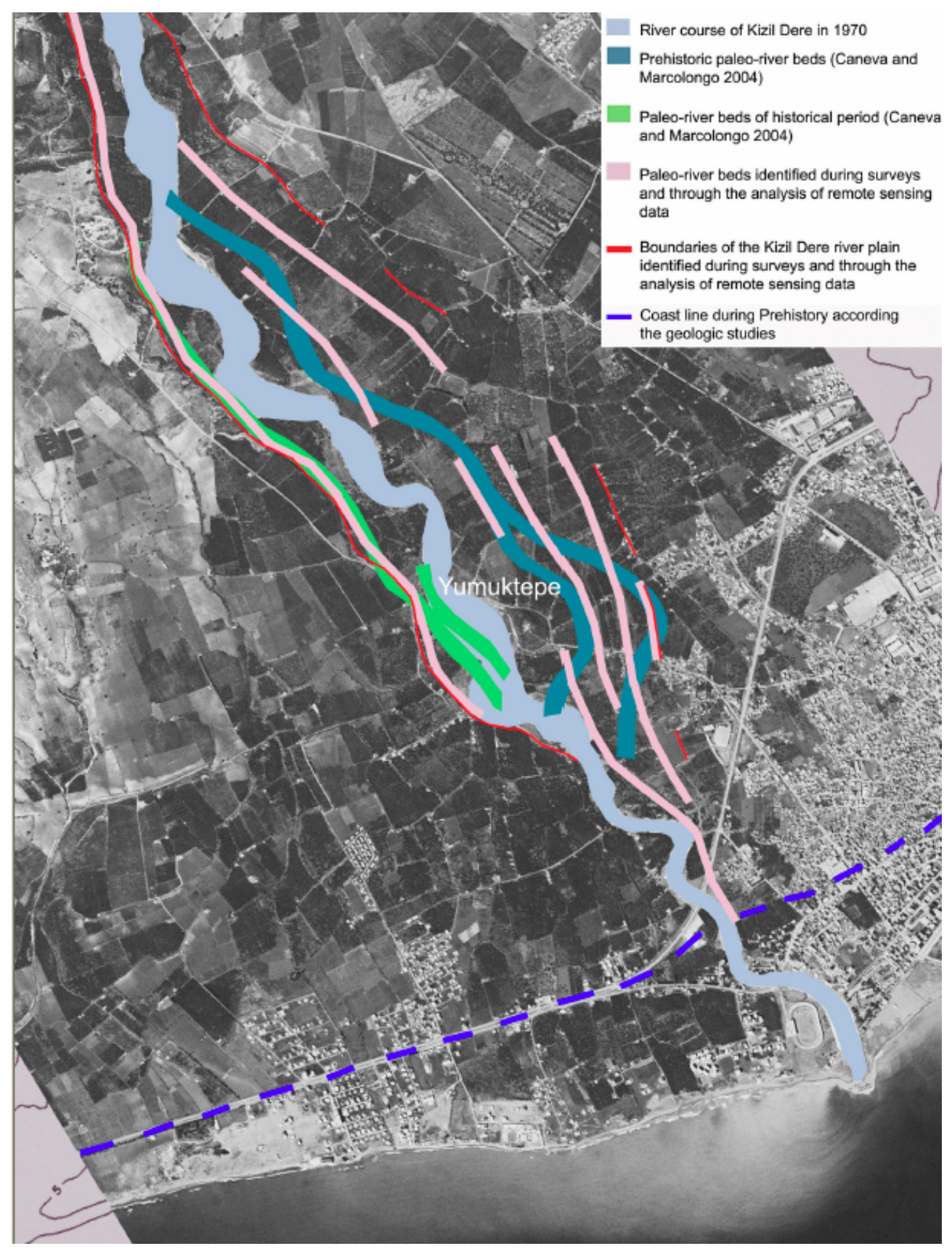

Fig. 8. Corona KH-4B image of 1970 georeferenced on a topographic map of the Yumuktepe area: paleo-river beds of the Kizil Dere and the ancient coast line are showed.

images, was very important. These photos documented the paleo-beds of the Berdan, Seyhan and Ceyhan rivers which formed the Adana plain with their sediments, causing its enlargement also in historic times, and forming one of the biggest delta in Turkey, in the southern sector of the plain. It is sufficient to keep in mind the situation of the Roman town of Tarsus, along the Berdan river course, that was reached by ship by Anthony and Cleopatra and that today is located $14 \mathrm{~km}$ from the coastline. The DEM facilitated the exami- nation of the vast area, in which only surveys were carried out and allowed us to associate the morphological data to the archaeological and paleo-environmental traces and elements that were visible in the remote sensed images. It was additionally possible to locate the reliefs of the various tells of protohistoric date that characterize the area (that were often settled continuously also in historic times) and the few high grounds existing in the plain, that with their presence determined the course of the main rivers. The historic images, 


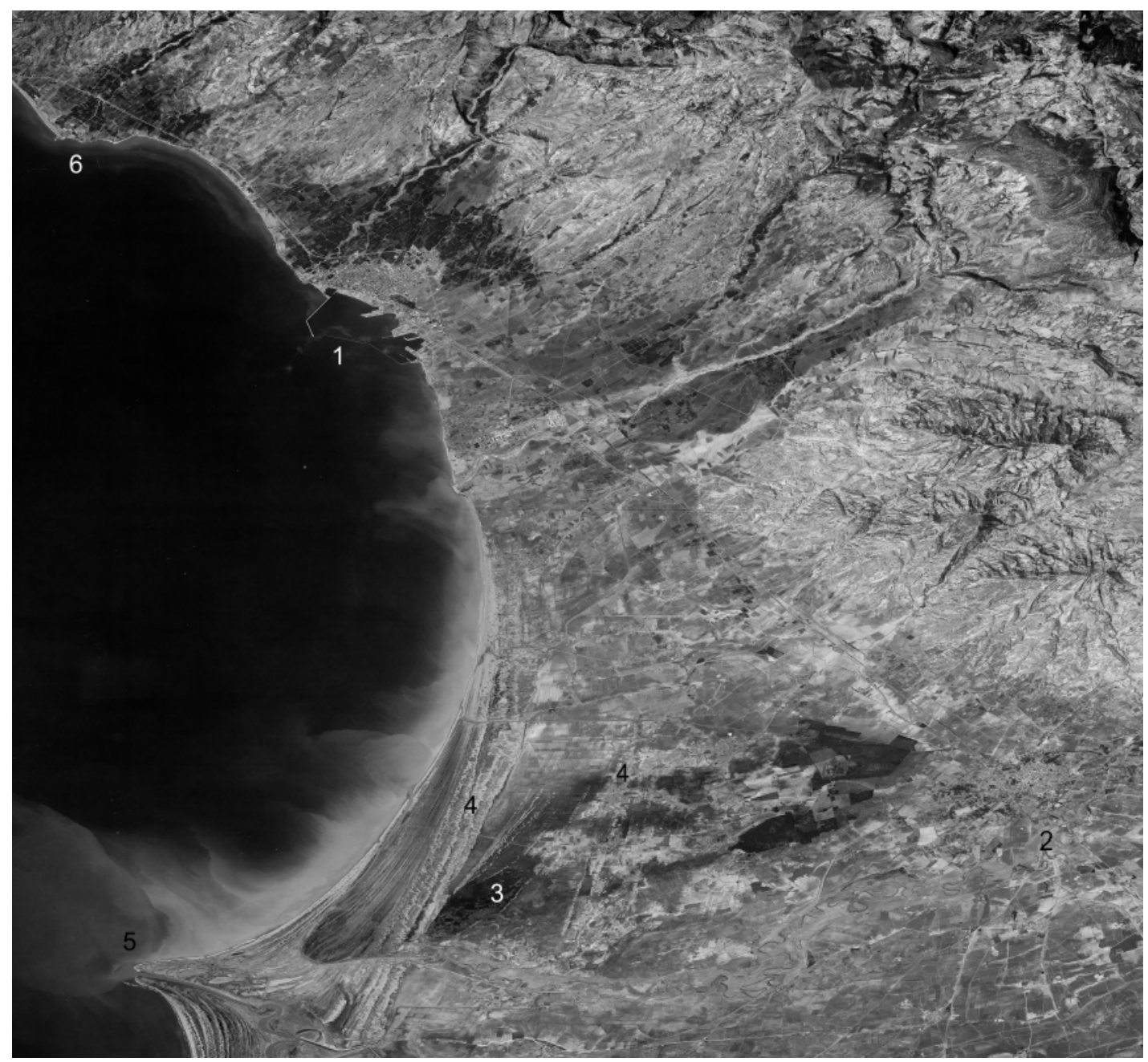

Fig. 9. The territory of Mersin (1) and Tarsus (2) in a Gambit KH-7 photo of 1967, with a large trace of residual humidity (3) and the dunes (4) between the second city and the sea; the delta of the Berdan and Seyhan rivers (5) and the site of the ancient city of Soloi (6) are also visible.

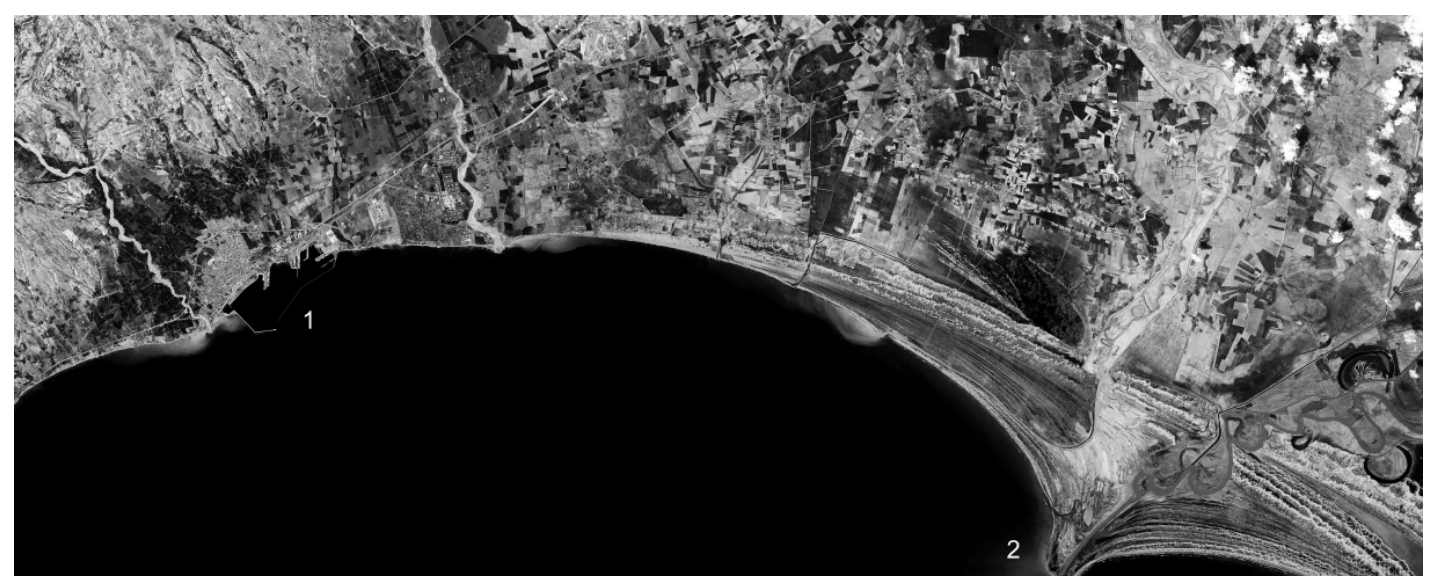

Fig. 10. The territory between Mersin (1) and the delta of the Berdan and Seyhan rivers (2) in a Corona KH-4B photo of 1970: the meandering courses of the two rivers, the coastal dunes and the traces of residual humidity behind them are visible. 
instead, clearly document the tells that are now destroyed or transformed and the dune lines of the coast's widening between Mersin and the centre, with the significant placename of Karatas ("black stone" in Turkish). It is located on a coastal relief that determined the sharp turn eastwards of the last stretch of the river Ceyhan. Such lines are at the origin of the coastal lakes that characterize the area, today partially transformed, compared to a few years ago, by the proliferation of industrial plans and of the use of machinery in agriculture. In conclusion, the traces of residual humidity visible in the satellite images of 1960's document several lagoons nowadays filled in, and quite far from the coast (Figs. 9-10), especially in the area of Tarsus. This proves how the ground has substantially advanced to the detriment of the sea. The analysis of archaeological remains in the Adana plain (where in the southern part an occupation from the Bronze age is documented) combined with remote sensing observation has dated this phenomenon particularly to the protohistoric and historic times and after the earliest Yumuktepe settlement which was established on recent marine sediments.

Acknowledgements. I thank Anna Maria Bietti Sestieri and Isabella Caneva for letting me take part in the research concerning the Specchia Artanisi and the Yumuktepe. I also thank the Director of the State Archive of Viterbo, Dr. Augusto Goletti, and his staff for their courteous and helpful assistance in enabling me to consult the aerial photos of the "Fondo S.A.R.A. - Ala Littoria S.A.". Finally I thank Giovanna Occhilupo for information regarding the historical maps of Salento preserved in the National Library of Naples.

Edited by: L. Eppelbaum, N. Masini, and F. Soldovieri

Reviewed by: two anonymous referees

\section{References}

Auriemma, R.: Salentum a salo. Forma Maris Antiqui, Congedo Editore, Galatina, 2004.

Beck, A. R., Philip, G., Abdulkarim, M., and Donoghue, D. N. M.: Evaluation of Corona and Ikonos high resolution satellite imagery for archaeological prospection in western Syria, Antiquity, 81, 161-175, 2007.

Beck, A. R., Philip, G., Donoghue, D. N. M., and Galiatsatos, N.: Geo-locating Corona imagery for archaeological surveys and cultural resource management: a case study in Syria, in: volo nel passato: aerofotografia e cartografia archeologica, edited by: Musson, C. Palmer, R., and Campana, S., All'Insegna del Giglio, Firenze, 295-299, 2005.

Beck, A. R., Philip, G., and Wilkinson, K. N.: Satellite imagery as a resource in the prospection for archaeological sites in central Syria, Geoarchaeology, 21, 7, 735-750, 2006.

Boemi, M. F.: Le raccolte aerofotografiche, in: Lo sguardo di Icaro. Le collezioni dell'Aerofototeca Nazionale per la conoscenza del territorio, edited by: Guaitoli, M., Campisano Editore, Roma, 29-42, 2003.

Caneva, I. and Marcolongo, B.: The history of the mound, in: Mersin-Yumuktepe a Reappraisal, editeb by: Caneva, I., Sevin, V., Congedo Editore, Galatina, 23-31, 2004.
Caneva, I. and Sevin, V. (Eds.): Mersin-Yumuktepe a Reappraisal, Congedo Editore, Galatina, 2004.

Caprasecca, A.: A historic flight and the study of archaeological landscape in Maremma (Central Italy), in: From Space to Place. Proceedings of the 2nd International Conference on Remote Sensing in Archaeology, (Rome, 4-7 December 2006), edited by: Campana, S. and Forte, M., BAR International Series 1568, Oxford, 43-46, 2006a.

Caprasecca, A.: Un volo aereo storico per lo studio del paesaggio antico in Maremma, Sci. Tech. Cult. Herit., 15, 1-2, 41-48, 2006 b.

Dadamo, M., Zaccarelli, N., Zecca, S., and Zurlini, G.: Traiettorie evolutive della fascia costiera: il caso del litorale di Ugento (Prov. Lecce), in Atti del II Simposio Internazionale "Il monitoraggio costiero mediterraneo: problematiche e tecniche di misura" (Napoli, 4-6- giugno 2008), 67-74, 2008 a.

Dadamo, M., Petrosillo, I., Zaccarelli, N., and Zurlini, G.: Approccio integrato per la comprensione della dinamica storica dei Paesaggi culturali della Provincia di Lecce, in Atti del XVIII Congresso della Società Italiana di Ecologia (Parma 2008), 2008 b.

D'Alessandro, A., Loiacono, F., Ricchetti, G.: Note illustrative alla carta geomorfica del Salento meridionale (F. 525 "Gallipoli", 526 "Nardò", 527 "Otranto", 536 "Ugento" e 537 "Capo S. Maria di Leuca"), in Atti Convegno sulle "Conoscenze Geologiche del Territorio Salentino", Quaderni di Ricerche del Centro Studi Geotecnici e di Ingegneria, 11, 207-222, 1987.

D'Andria, F.: Ugento. Torre S. Giovanni, Studi Etruschi, XLVI, 564-565, 1978.

D'Andria, F.: La documentazione archeologica medioevale nella Puglia meridionale, in Le aree omogenee della civiltà rupestre nell' ambito dell'Impero Bizantino: la Serbia, Congedo Editore, Galatina, 223-228, 1979.

D'Andria, F.: Lo Zeus stilita di Ugento e il capitello di Vaste. Nota, Taras, III, 1-2, 155-162, 1983.

D’Andria, F.: Messapi e Peuceti, in Pugliese Carratelli G. (a cura di), Italia omnium terrarum alumna, Milano, 653-715, 1988.

D'Andria, F.: Insediamenti e territorio: l'età storica, in I Messapi. Atti del Convegno di Studi sulla Magna Grecia, 30, 1990, Taranto, 393-478, 1991.

Desy, Ph.: Réflexions sur l'économie et le commerce du Sallentin hellénistique à propos d'amphores inédites de Gallipoli et d'Ugento, Antiquité Classique, LII, 175-194, 1983.

Desy, Ph. and De Paepe, P.: Torre S. Giovanni (Ugento) les amphores commerciales hellénistiques et républicaines, Studi di Antichità, 6, 187-234, 1990.

Gasperoni, T. and Scardozzi, G.: Bomarzo, Mugnano, Bassano in Teverina. IGM F. 137, I SO "Attigliano" - II NO "Soriano nel Cimino". Carta Archeologica d'Italia, Contributi, Viterbo, in press, 2010.

Galiatsatos, N.: Assessment of the Corona series of satellite imagery for landscape archaeology. A case study from the Orontes valley, Syria, Thesis for the degree of Doctor of Philosophy, University of Durham, 2004.

Goossens, R., De Wulf, A., Bourgeois, J., Gheyle, W., and Willems, T.: Satellite imagery and archaeology: the example of Corona in the Altai Mountains, J. Archaeol. Sci., 33, 6, 745-755, 2006.

Guaitoli, M. (Ed.): Lo sguardo di Icaro. Le collezioni dell'Aerofototeca Nazionale per la conoscenza del territorio, Campisano Editore, Roma 2003. 
Lamboley, J.-L.: Recherches sur les Messapiens. IV $^{e}-\mathrm{II}^{e}$ siècle avant J.-C., Roma, Italy, 1996.

Lezzi, M.: Le paludi e la bonifica nel territorio di Salve, Annu Novu, Salve Vecchiu, XI, 66-82, 2000.

Mastronuzzi, G., Palmentola, G., and Sansò, P.: Osservazioni sulle caratteristiche fisiografiche dei litorali del Salento meridionale. Atti Convegno sulle "Conoscenze Geologiche del Territorio Salentino", Quaderni di Ricerche del Centro Studi Geotecnici e di Ingegneria, 11, 223-241, 1987.

Piccarreta, F. and Ceraudo, G.: Manuale di aerofotografia archeologica. Metodologia, tecniche e applicazioni, Edipuglia, Bari, 2000.

Pizzurro A.: Ozan. Ugento dalla Preistoria all'Età Romana, Lecce, Italy, 2002.

Scardozzi, G.: Fotografie aeree storiche e ricerche di topografia antica nell'Etruria meridionale interna, Archeologia Aerea. Ricerche di Aerotopografia Archeologica, III, 21-59, 2008a.

Scardozzi, G.: Old high resolution satellite images for landscape archaeology: case studies from Turkey and Iraq, in Remote Sensing for Environmental Monitoring, GIS Applications, and Geology, Proceedings of SPIE Europe Remote Sensing, Conference 7110 "Remote Sensing and Archaeology", Cardiff, 1518 September 2008, 7110/03, 1-14, 2008b.
Scardozzi, G.: Topografia antica dell'area della Specchia Artanisi, in AA.VV., Ugento: ricerche archeologiche sulla Specchia Artanisi e sul territorio circostante, Ugento, 15-24, 2009.

Schmiedt, G.: Antichi porti d'Italia. Gli scali fenicio-punici. I porti della Magna Grecia, I. G. M., Firenze, 1975.

Semeraro, G.: $\varepsilon v v \eta v \sigma$, ceramica greca e società nel Salento arcaico, Edipuglia, Lecce-Bari, 1997.

Ur, J. A.: Sennacherib's northern Assyrian canals: new insights from satellite imagery and aerial photography, Iraq, 67, 317-345, 2005.

Ur, J. A.: Agricultural and Pastoral Landscapes in the Near East: Case Studies using Corona Satellite Photography, ArchAtlas, edition on-line, 2007.

Urso, P.: Ugento attraverso la storia, Taranto, 1941.

Wilkinson, T. J., Wilkinson, E.B ., Ur, J. A., and Altaweel, M. R.: Landscape and settlement in the Neo-Assyrian Empire, Bulletin of the American Schools of Oriental Research, 340, 23-56, 2005.

Zecca, S.: Portus Uxentinus vel Salentinus, Ed. Mariano, Galatina, 1963. 